\begin{tabular}{|c|c|c|}
\hline Етап & Міждисциплінарні зв'язки & Тематичні блоки іншомовної підготовки \\
\hline & & $\begin{array}{l}\text { Ділова комунікащія } \quad \text { (співбесіда, } \\
\text { документи для працевлаштування) }\end{array}$ \\
\hline Спеціалізація & $\begin{array}{c}\text { Економіка підприємства } \\
\text { Державне управління } \\
\text { економічною сферою } \\
\text { Зовнішньоекономічна } \\
\text { діяльність }\end{array}$ & $\begin{array}{l}\text { Менеджмент (завдання, діяльність, } \\
\text { функції менеджера) } \\
\text { Німецькомовні країни у світовій } \\
\text { економіці, співробітництво з Украӥною; } \\
\text { Національні й міжнародні підприємства } \\
\text { йорганізації; } \\
\text { Банкові системи, валюти; } \\
\text { Бюджет, податки. }\end{array}$ \\
\hline
\end{tabular}

Наведені в таблиці теми мають рекомендаційний характер і можуть варіюватися залежно від профілю університету, спеціалізації та навчальних можливостей студентів. Доцільно орієнтуватися на фаховий зміст вже з початку навчання в університеті, тобто 3 першого семестру. Водночас, слід звернути увагу на те, що результативним навчальний процес на початковому етапі з іноземної мови фахового спрямування буде лише за умови, якщо фаховий зміст складатиме лише третину від загальної кількості годин.

Отже, пропонований курикулум для економістів розробляється на основі «Рамкової програми 3 німецької мови професійного спілкування», що певною мірою сприяє стандартизації іншомовної підготовки майбутніх економістів. Курикулум з ділової німецької мови описує рамкові умови викладання німецької мови для економістів, за яких навчання іноземної мови відбувається 3 використанням міждисциплінарних зв'язків, із залученням фахових знань економістів та 3 опорою на вже відомий фаховий зміст навчання згідно 3 навчальним планом як на рівні базової економічної освіти, так і на рівні спеціалізації. Такий курикулум може доповнюватися залежно від потреб, але слугуватиме основою для розроблення навчальних програм і надасть змогу уніфікувати підходи до визначення рівня знань студентів-економістів.

\title{
Література
}

1. Амеліна С. М. Рамкова програма 3 німецької мови для професійного спілкування для вищих навчальних закладів України / С. М. Амеліна, В. А. Гаманюк та ін. - Київ : Ленвіт, 2014. - 136 с. 2. Жданова Н. С. Зміст і структура навчально-методичного комплексу 3 німецької мови для майбутніх менеджерів : дис. ... канд. пед. наук : 13.00.02/ Наталія Сергіївна Жданова. - Київ, 2008. - 344 с.

\section{ОНОВЛЕННЯ ЗМІСТУ ПРОФЕСІЙНОЇ ОСВІТИ І НАВЧАННЯ: СУЧАСНІ ТЕНДЕНЦІЇ Й НАПРЯМИ}

Кантур О. В. Оновлення змісту професійної освіти і навчання: сучасні тенденції й напрями.

У статті розкриваються основи, обгрунтовується актуалізація процесу стандартизації професійної освіти. Аналізуються етапи розробки освітніх стандартів нового покоління на прикладі підготовки працівників туристичної сфери. Характеризується зміст розробленого державного стандарту професійно-технічної освіти на основі компетенцій для робітничої професії.

Ключові слова: модернізація освітньої системи, зміст професійної освіти, 
стандартизація, державний стандарт, компетенції, працівники туристичної сфери.

Кантур Е. В. Обновление содержания профессионального образования и обучения: современные тенденции и направления.

В статье раскрываются основы, разъясняется актуализация процесса стандартизации профессионального образования. Анализируются этапы разработки образовательных стандартов нового поколения на примере подготовки работников туристической сферы. Характеризуется содержание разработанного государственного стандарта профессиональнотехнического образования на основе компетенций для рабочей профессии.

Ключевые слова: модернизация образовательной системы, содержание профессионального образования, стандартизация, государственный стандарт, компетенции, работники туристической сферы.

Kantur O. V. Updating the content of vocational education and training: modern trends and directions.

The article describes the foundation, and explains the process of development of vocational education standards. It also analyzes the stages of new generation of educational standards development by the example of the vocational training for tourism industry. The content of the developed state standard of vocational education is characterized based on competences for the profession.

Key words: the modernization of the educational system, the content of vocational and training education, standardization, state standards, competencies.

На початку XXI століття ми є свідками глобальної інтеграції, яка поєднує держави, ринки, технології. Світ стає єдиним цілим у фінансово-економічному, інформаційному та технологічному аспектах, а також у культурно-духовній сфері, зокрема - в освіті.

Процес об'єднання Європи, його поширення на схід супроводжується формуванням спільного освітнього і наукового простору та розробленням єдиних критеріїв і стандартів у цій сфері в масштабах усього континенту. Як зазначено у Національній Стратегії розвитку освіти в Україні на 2012-2021 pр., найактуальнішим напрямом розвитку освіти, зокрема професійно-технічної, постає створення системи забезпечення iї якості шляхом розроблення сучасних державних стандартів з професій широких кваліфікацій. Реформування системи освіти, в основу якої покладатиметься принцип пріоритетності розвитку людини, розглядається невід'ємно від модернізації структури, змісту й організації освіти на засадах компетентнісного підходу, що сприятиме інтеграції національної системи освіти в європейський і світовий освітні простори [1].

Наша країна прагне до якісної освіти, яка розглядається як інструмент соціальної та культурної злагоди й економічного зростання. Сучасні реформи в галузі професійнотехнічної освіти (ПТО) не повною мірою задовольняють потреби особистості, суспільства $\mathrm{i}$ держави. Необхідним є оновлення змісту ПТО відповідно до потреб ринку праці в Україні задля визначення й подальшого використання конкретних механізмів забезпечення якісної підготовки конкурентоспроможних робітників. До таких механізмів передусім належать професійні стандарти нового покоління.

Проблеми підготовки та відбору кадрів, чиї знання, вміння, компетенції та рівень кваліфікації найбільш точно відповідають вимогам діяльності будь-якої організації України чи світу, зберігають свою актуальність і донині. Необхідність створення і впровадження

Педагогіка вищої та середної школи. - 2015. - Вип. 45 
нових, більш ефективних та надійних підходів і методів професійної дії конкретної сфери економіки зумовлюється зростаючою значущістю людського капіталу у подоланні соціально-економічних проблем сучасного суспільства.

Адже процес підготовки робітників високої кваліфікації потребує оптимізації та поглиблення базових знань, диференціації й інтеграції змісту освіти за основними напрямами майбутньої професійної діяльності; посилення професійної орієнтації, розвитку нестандартного і творчого мислення, дослідницьких умінь. Підготовка кваліфікованих фахівців такого рівня може здійснюватися на базі професійних навчальних закладів (ПНЗ професійно-технічні навчальні заклади, технікуми тощо) за умов обгрунтованої інтенсифікації освітнього процесу, досягнення глибокої інтеграції навчальних програм із кількох професій, використання інформаційних і педагогічних технологій [7, с. 235].

Принципово нова політична, економічна й соціальна ситуація, що склалася в Україні, iï вихід як самостійного суб'єкта на міжнародну туристичну карту, визнання національних культурних пам'яток, організація рекреаційно-туристичних зон - усе це потребує наукового обгрунтування теоретичних і методичних засад підготовки робітників для сфери туризму.

Необхідність пріоритетного розвитку системи туристської освіти, підвищення її ролі в модернізації туристської галузі потребують розроблення державних стандартів туристської освіти, обгрунтування підходів до відбору і структурування ii змісту та програмнометодичного забезпечення професійної підготовки у навчальних закладах.

Проблема процесу стандартизації та модернізації освітньої галузі в Україні досліджувалася багатьма вітчизняними та зарубіжними науковцями. Варто зазначити, що, безумовно, необхідним є міждисциплінарний підхід до процесу розроблення стандартів для підготовки майбутніх кваліфікованих робітників, який є перехрестям для педагогічних, філософських, соціальних, культурологічних аспектів. Відомі праці вітчизняних науковців Т. Десятова, С. Мельника, Н. Ничкало, І. Савченко, Н. Фоменко були присвячені методологічним підходам щодо розроблення стандартів різних поколінь. В. Супрун приділяв увагу розробленню Національної рамки кваліфікацій як основи стандартизації ПТО [8].

У дослідженнях зарубіжних науковців 3 цієї проблеми приділяється увага особливостям розробки професійних освітніх програм на основі вимог роботодавців (I. Волошина, 3. Якімова та ін.). Дослідники О. Олейнікова, А. Муравйова визначають професійний стандарт як докладну характеристику рівня виконання конкретного виду професійної діяльності, що визначається компетенціями. На думку цих дослідників, саме через компетенції, що становлять здатність особи застосовувати знання, уміння та практичний досвід у знайомих і незнайомих трудових ситуаціях, стандарті описуються вимоги сфери праці до працівників та результати, які повинні бути досягнуті ними у відповідності до цих вимог [5, с. 69].

Аналіз наукових праць дозволив з'ясувати, що стандарти розробляються i використовуються, поштовхом для чого $\epsilon$ існуючи проблеми, які потребують спільних професійних рішень. Однак, і сьогодні розроблення стандартів ПТО на практиці залишається проблемою не тільки методологічного, але й організаційного, нормативно-правового, інформативного характеру.

Mema cmammi- схарактеризувати зміст розробленого державного стандарту професійно-технічної освіти на основі компетенцій із робітничої професії.

Професійну освіту нині можна розглядати як експериментальний майданчик розвитку держави і суспільства. Вона є не тільки об'єктом, але і суб'єктом модернізації. Сфера освіти перейшла у сферу стратегічних інтересів держави, претендуючи на роль могутнього 
інструменту консолідації суспільства.

Як визначала академік Н. Ничкало, ще на початку 2000-х років, процес оновлення змісту ПТО є складним, довгостроковим, копітким і суперечливим, а тому, на іiі думку, стандартизація професійної освіти не може обмежуватися рамками освітнього простору. Вивчення комплексної проблеми підготовки трудового потенціалу країни, а також особливостей розвитку ринку праці викликає необхідність консолідації зусиль органів законодавчої влади, представників підприємств, навчальних закладів, наукових установ по створенню професійних стандартів, особливістю яких є урахування вимог роботодавців щодо наявності у кваліфікованого робітника не тільки знань, умінь та навичок, але i специфічного уміння виконувати обов'язки в рамках 4 основних професійних видів діяльності, пов'язаних зі ступенем сформованості професійних і ключових компетенцій [4, c. 138].

Формуванню компетенцій у процесі професійно-технічного навчання (ПТН) сприяє модульна технологія побудови змісту освіти, яка забезпечує розвиток потреб і здатностей учнів, досягнення й отримання високого рівня кваліфікацій, що дозволяє їм бути конкурентоспроможними на ринку праці. Зародження ідеї модульного навчання пов'язане 3 виникненням зарубіжної концепції одиниць змісту освіту ще наприкінці XX століття

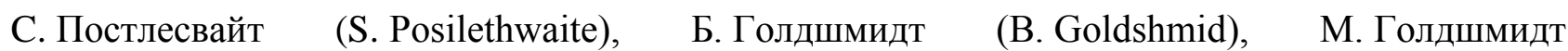
(M. Goldshmid), Дж. Рассел (J. Russel), мета якої полягає в тому, що відносно невелику частину навчального матеріалу доцільно брати за автономну тему і вільно вносити до змісту програми курсу навчання [9].

Слід зауважити, що важливою особливістю модульного навчання $є$ відсутність жорстких організаційних тимчасових рамок навчання. Дж. Рассел стверджує, що модульне навчання вимагає безпосередньої відповідальності учня за результат навчання, оскільки для нього створюються комфортні умови для засвоєння змісту модулів. За такого підходу суттєво збільшується мотивація навчання, оскільки учень може вільно вибирати зручні для нього способи, засоби і темпи навчання [9, с. 52].

Комбінування модульної технології побудови змісту освіти та компетентнісного підходу надало змогу запропонувати інноваційну технологію навчання - модульнокомпетентнісну, при якій поняття «компетенція і компетентність» набувають першорядного значення на відміну від традиційних понять «знання, уміння, навички». Такий підхід забезпечує учнів необхідними професійними, ключовими, соціальними та комунікативними компетенціями.

Проблеми оновлення змісту ПТО на основі стандартизації, упровадження модульнокомпетентнісного підходу для підготовки конкурентоспроможних робітників, здатних гнучко реагувати на зміни, що відбуваються на ринку праці $є$ важливими для усіх галузей промисловості та сфери послуг. Не $є$ винятком і туристична галузь як одна 3 основних галузей української економіки сьогодні.

Доцільність підготовки робітників за професією «Агент 3 організації туризму» зумовлена сукупністю зовнішніх i внутрішніх чинників, що визначають нинішній стан $\mathrm{i}$ перспективи розвитку туристської галузі в Україні. До зовнішніх чинників слід віднести те, що після Другої світової війни туризм у світі став глобальним загальнолюдським явищем та поступово набув трансконтинентальних вимірів, викликавши необхідність налагодження міждержавного співтовариства в цій галузі.

До внутрішніх чинників віднесено: об’єктивні потреби піднесення питомої ваги України у світовому туризмі, створення і розвиток української системи туристської освіти; 
необхідність концептуального обгрунтування розроблення і законодавчого закріплення державної політики в цій галузі та науково-методичного забезпечення iї реалізації на загальнодержавному, регіональному рівнях та на рівні навчального закладу.

До проведення експерименту всеукраїнського рівня був залучений ДНЗ «Одеське вище професійне училище морського туристичного сервісу», який і став експериментальним майданчиком дослідження.

Загальна тривалість педагогічного експерименту становила 5 років, з вересня 2009 по липень 2014 рр. Дослідницько-експериментальна робота і педагогічне спостереження проводилися в 3 етапи. Термін першого етапу (аналітико-діагностичного) - 1 рік; другого (формувального) - 3 роки; третього (узагальнюючого) - 1 рік.

На першому етапі відбувався процес систематизації й аналізу:

- законодавчої та нормативної документації за темою дослідження;

- наукових і методичних джерел щодо європейського досвіду підготовки фахівців на основі ключових компетенцій;

- статистичних даних 3 питань технологічного розвитку підприємств туристичного бізнесу в Одеській області та Україні в цілому.

На цьому етапі дослідження також відбулося анкетування працівників туристичних агентств, бесід з питань змісту і принципів побудови проектів державних стандартів ПТО на основі компетенцій; оброблення та узагальнення анкет підприємств, задіяних у експерименті; розроблення експериментальної документації щодо компетенцій i кваліфікаційних рівнів робітничих професій сфери туризму з урахуванням рекомендацій підприємств галузі.

На другому етапі відбулася апробація програмно-методичних матеріалів професійного навчання кваліфікованих робітників з професій туристичної галузі відповідно до проектів державних стандартів ПТО на основі компетенцій робітників туристичної сфери, а також, як наслідок, коригування змісту проектів державних стандартів ПТО, навчально-методичних, програмних матеріалів.

Узагальнення опрацьованого експериментального матеріалу стало результатом третього етапу експерименту. Було підведено підсумки дослідження, сформульовані основні висновки, а також перспектив подальшого дослідження обраної теми.

Відповідно до вимог модульно-компетентнісного підходу було розроблено модульний навчальний план професійного стандарту, який складався 34 навчальних модулів, які були диференційовані згідно конкретної теми та систематизовані, а також являли собою логічно завершену одиницю навчального матеріалу, цільову програму дій і методичні вказівки.

Кожен навчальний модуль складався з відповідної кількості структурних навчальних елементів, які містили у собі послідовний, логічно завершений навчальний матеріал, що забезпечував розуміння та засвоєння необхідного матеріалу та здобування відповідних знань для реалізації набутих професійних та ключових компетенцій.

Кожен структурний елемент професійного стандарту розкладався на одиниці, які містили розгорнуту характеристику конкретної трудової функції, яка була цілісною, завершеною, відносно автономною i значущою для даного виду трудової діяльності. Безпосередньо вказані відповідні трудові дії, професійні, ключові та наскрізні компетенції, засоби та предмети праці.

Професійний стандарт компетентності був складений із удосконалених у результаті анкетування туристичних підприємств України, професійних компетенцій, підтверджених 
загально-професійних компетенцій, відповідних ключових компетенцій, з урахуванням сучасних технологічних процесів, сучасних методів праці, 3 урахуванням регіональних особливостей галузі, потреб роботодавців і містив вимоги до рівня знань, умінь та навичок.

Професійно-практична підготовка здійснювалася в туристичних підприємствах безпосередньо на робочих місцях туристичних агентів.

Після завершення кожного модуля проводилася проміжна атестація 3 теоретичних предметів, після чого здійснювалася професійно-практична підготовка безпосередньо на робочих місцях у туристичних підприємствах, завершався кожний модуль проміжною атестацією. Після закінчення останнього четвертого модуля проводилася державна кваліфікаційна атестація.

Завдяки реалізації програми діяльності експериментального педагогічного майданчика стало можливим обгрунтувати концептуальні положення щодо оновлення змісту професійної освіти через упровадження компетентісних підходів до підготовки робітників професій туристичної сфери в професійно-технічних навчальних закладах (ПТНЗ), підкреслити його безперечний вплив на формування професійно-важливих якостей майбутнього кваліфікованого робітника. Доведено необхідність детальної організації професійного навчання майбутніх кваліфікованих робітників туристичної галузі у ПТНЗ, необхідність тісної та плідної співпраці з роботодавцями, необхідність розроблення якісних компетентісних підходів до оволодіння професіями туристичної сфери задля реалізації професійних функцій робітника. Також постала проблема 3 необхідністю підготовки педагогічних кадрів, спроможних реалізовувати програму професійно-технічної освіти за рівнями компетенцій.

Отже, аналізуючи організацію навчального процесу згідно 3 експериментальним навчальним планом можна виокремити такі переваги та недоліки, які мали місце на етапі практичної реалізації експериментального плану. Серед переваг можна відмітити підвищення мотивації учнів завдяки модульної системи навчання та інноваційних педагогічних технологій, які надали змогу майбутнім робітникам відкрити в себе прагнення до навчання упродовж усього терміну, інтерес до самостійної роботи, до творчого пошуку, підвищення бажання отримання найкращого результату. За результатами Державної кваліфікаційної атестації наприкінці 2013-2014 н. p. ефективність роботи за експериментальним навчальним планом становила 71 \% учнів 3 високим рівнем та $29 \% 3$ достатнім рівнем навчальних досягнень.

Слід зауважити, що серед недоліків, які виявлено в процесі апробації, окрім виявленого браку часу на таку дисципліну, як «Іноземна мова за професійним спрямуванням», також виникли труднощі з наданням робочих місць для відпрацювання тем професійно-практичної підготовки (власники туристичних фірм не завжди були готові віддавати свій час на навчання тих, хто нині тільки отримує туристичну освіту).

Оновлення змісту ПТО та підвищення ії якості не можливо без подолання певних «проблемних зон», але розглядаючи розробку професійних стандартів, як необхідну сходинку у глобальної освітньої інтеграції, необхідно зазначити, що учень, отримавши певні компетенції задля досягнення успіху у професійній сфері, повинен уміти використовувати їх у практичній діяльності, а тому професійно-практична підготовка потребує уваги та подальшого пошуку шляхів підвищення якості підготовки робітників у сфері туризму, а також активізації співпраці професійних навчальних закладів 3 професійним середовищем, громадськими організаціями та державними установами. Ми вважаємо, що є доцільним надавати можливість ПТНЗ на експериментальних засадах розробляти та проводити процес 
апробації професійних стандартів підготовки майбутніх робітників.

Аналізуючи сучасні тенденції оновлення змісту освіти, зауважимо, що створення системи стандартизації освітньої діяльності сприяє підвищенню якості освіти. Ринок праці визначає потребу у кваліфікованих робітниках, у високому рівні їх компетенції. Відповідно до цього необхідно удосконалювати і формувати новий зміст ПТО та визначати алгоритм інноваційного стилю діяльності.

\section{Література}

1. Указ Президента України № 344/2013 від 25 червня 2013 р. «Про Національну стратегію розвитку освіти в Україні на період до 2021 року» [Електронний ресурс].Електронні дані. - Режим доступу: http:// www.president.gov.ua/documents/15828. 2. Десятов Т. М. Національна кваліфікаційна рамка - інструмент модернізації освіти i навчання / Т. Десятов // Професійно-технічна освіта. $-\quad 2010 .-$ № 1. - С. 10-13. 3. Мельник С. Іспанський досвід розробки національної системи кваліфікацій / С. Мельник // Професійно-технічна освіта: [науково-методичний журнал]. - 2010. - № 1. С. 21-26. 4. Ничкало Н. Г. Шляхи розв'язання проблем / Н. Г. Ничкало // Профтехосвіта України: ХX століття: Енциклопедичне видання / ред. Н. Г. Ничкало. - Київ : Видавництво «АртЕк», 2004. - С. 138. 5. Олейникова О. Н. Профессиональные стандарты - основной критерий повышения качества профессионального образования / О. Н. Олійникова, А. А. Муравьева // Образование в документах. - 2007. - № 21.- С.67-74. 6. Савченко І. М. Особливості стандартизації в системі початкової професійної освіти РФ: дис. ... канд. пед. наук: 13.00.04 / Савченко Ірина Миколаївна. - Київ, 2012. - 253 с. 7. Сергеєва Л. М. Прогнозування розвитку ринку праці як інструмент діалогу професійних навчальних закладів із соціальними партнерами /Л. М. Сергеєва // Педагогіка і психологія професійної освіти. - Львів, 2013. - № 6. - С. 235-242. 8. Супрун В. Профтехосвіта. Плани на майбутнє [Електронний ресурс].- Режим доступу: https://proftekhosvita.org.ua/uk/ news/details/5012 9. Russel J. D. Modular Instruction// A Guide to the Design, Selection, Utilization and Evaluation of Modular Materials. - Minneapolis, Minnesota : Burgess Publishing Company. - 1974. - 164 p. 10. Фоменко Н. А. Теоретико-методичні засади формування стандартів освіти у сфері туризму: автореф. дис. на здобуття наук. ступеня д-ра пед. наук: 13.00.04 / Н. А. Фоменко; Черкас. нац. ун-т ім. Б. Хмельницького. - Черкаси, 2012. - 40 с.

УДК 378.147:811.111(07)

Олена Катеруша, Людмила Коржова

\section{КЛЮЧОВІ КОМПЕТЕНЦЇ̈, ЇХ ФОРМУВАННЯ НА ЗАНЯТТЯХ 3 IHОЗЕМНОї МОВИ}

Катеруша О. В., Коржова Л.С. Ключові компетенції, їх формування на заняттях 3 іноземної мови.

У статті розкрито зміст ключових компетенцій, окреслено шляхи й етапи їх формування на заняттях 3 іноземної мови. Доведено, що зміст ключових компетенцій визначається низкою соціально-комунікативних та професійно-комунікативних умінь, способів комунікативної поведінки, рішенням проблемних завдань в умовах соціально- i професійно-орієнтованих ситуацій спілкування.

Ключові слова: ключові компетенції, професійна компетенція, соціальнокомунікативна компетенція, компетенція самоврядування, комунікативна поведінка. 